ISSN 2077-1827. Гуманізація навчально-виховного процесу. 2020, №. 1 (99)

РОЗДІЛ. ДОШКІЛЬНЕ ВИХОВАННЯ

ability composeareflective narration in senior preschool-age children. There are the following types of exercises among them: analytical, constructive and creative ones.

Conclusions. Hereby, we consider exercises as one of the leading methods for developing the skills of senior preschool-age children to compose reflective narrations, which allows the development of speech competence in the development of a special system of exercises and its systematic use at the lessons relating to development of native speech atpreschool education establishments.

\title{
REFERENCES
}

1. Bohush, A. M., Havrysh, N.V. (2011). Preschool linguodidactics: theory and methods of teaching mother language in preschool educational institution. Kyiv: Slovo. (in Ukr.)

2. Dictionary-directory on Ukrainian linguistics (2003). ). In M. I. Pentyliuk (Ed.). Kyiv: Lenvit. (in Ukr.)

3. Methods of teaching the Ukrainian language in secondary schools (2009). In M. I. Pentyliuk (Ed.). Kyiv: Lenvit. (in Ukr.)

4. Bohush A. M. (2004). Speech development of children from birth to 7 years. Kyiv: Slovo. (in Ukr.)

5. Omelianenko A.V. (2009). Teaching older children to compose stories and reflections. Doneczk: Yugo-Vostok. (in Ukr.)

(переклав на англійську В. В. Богдан - доцент, канд. філол. наук, доцент кафедри іноземних мов i методики викладання Бердянського державного педагогічного університету)

\section{УДК 372. 3.03.2:172.3}

\section{КРИВОШЕЯ Неля}

канд. пед. наук, доцент кафедри дошкільної освіти, ДВНЗ «Донбаський державний педагогічний університет»

пров. Вчительський, 1, м. Слов’янськ, Донецька область, Україна

E-mail: krivosheyanb@gmail.com

\section{ФОРМУВАННЯ ТОЛЕРАНТНОСТІ ДОШКІЛЬНИКА ЗАСОБАМИ РОДИННОГО ВИХОВАННЯ}

Анотація. У статті розкрито актуальність проблеми формування толерантності дітей дошкільного віку засобами родинного виховання. Зауважено, що готовність сприйняття інших такими, якими вони $\epsilon$, i взаємодіяти 3 ними на основі згоди є запорукою відродження й збагачення найвищих моральних ідеалів й життєвих пріоритетів людини.

Автором розглянуто сутність поняття «толерантність», проаналізовано роль гуманістичних цінностей суспільства як визначальних засад формування толерантності. Схарактеризовано роль сім'ї та взаємовідносин у родині, що обумовлюють формування толерантності дошкільників. Висвітлено поняття сімейної педагогіки толерантності, головним завданням якої визначено розвиток здатності до терпіння, витримки, самоконтролю та вміння вирішувати проблемні ситуації без агресії. Представлено основну мету виховання толерантності дошкільників у родині, яка полягає у формуванні особистості дитини, здатної до (C) Кривошея Н., 2020 
ISSN 2077-1827. Гуманізація навчально-виховного процесу. 2020, №. 1 (99)

РОЗДІЛ. ДОШКІЛЬНЕ ВИХОВАННЯ

безкорисної турботи та чуйності, доброзичливих емоційних проявів та емпатії, рівноправного та поступливого ставлення до оточуючих, позитивного прийняття себе та стриманого відстоювання своїх позицій, які виявляються в спілкуванні, вчинках та спільній діяльності.

Подальші перспективи дослідження автор визначає у вивченні шляхів, методів та прийомів органічної взаємодії сімейного виховання та педагогічного впливу в закладі дошкільної освіти для розвитку толерантності дошкільників.

Ключові слова: дошкільний вік, цінності, толерантність, формування особистості, родинне виховання.

Постановка проблеми у загальному вигляді та її зв'язок 3 важливими науковими чи практичними завданнями. Система освіти й виховання дітей та молоді в Україні є одним із найважливіших компонентів розбудови суспільства. Від ефективності освітньо-виховної діяльності в родинах і закладах дошкільної освіти багато в чому залежить спроможність українського суспільства відродити й збагатити найвищі моральні ідеали й життєві пріоритети людини. Сьогодні це як ніколи актуально, оскільки теперішній складний період позначений труднощами, дефіцитом моралі, культури взаємостосунків між людьми тощо. За таких обставин надзвичайно важливим стає виховання в молодого покоління, зокрема вихованців дошкільних закладів, готовності сприйняття інших такими, якими вони є, і взаємодіяти 3 ними на основі згоди, тобто толерантності.

Аналіз останніх досліджень i публікацій, в яких започатковано розв'язання даної проблеми і на які спирається автор, виділення невирішених раніше частин загальної проблеми, котрим присвячусться означена стаття. Цінності, їхня сутність, походження, класифікація та систематизація проаналізовані в роботах С. Аваліані, В. Андрущенка, Н. Бондаренко, В. Блюмкіна, М. Каган, I. Надольного, В. Тугаринова, В. Шинкарука та ін. Різні аспекти проблеми виховання толерантності досліджуються в сучасній педагогічній науці: загальні питання педагогіки толерантності (М. Рожков, А. Сиротенко, Г. Солдатова, Л. Шайгерова та ін.); етнічна толерантність (О. Докукіна, 3. Малькова, В. Подобєд, Ю. Римаренко, В. Тишков та ін.); технологічні питання виховання толерантності (Т. Білоус, О. Кащенко, Б. Рієрдон, В. Сітаров, I. Сковородкіна, О. Скрябіна, П. Степанов та ін.).

Формулювання цілей статті. Метою статті $\epsilon$ аналіз ролі родинного виховання у формуванні толерантної поведінки дітей дошкільного віку в контексті сучасних підходів до формування особистості.

Виклад основного матеріалу дослідження 3 повним обгрунтуванням отриманих наукових результатів. У період глобалізації, в результаті взаємодії культур та створення глобального простору, стикаються різні ціннісні системи та утворюється їх суміш. Соціокультурні трансформації, які $\epsilon$ результатом глобалізації, постають як причина руйнування традиційної системи цінностей, яка завжди була і залишається істотним чинником суспільної унікальності.

Система цінностей визначає культурну неповторність та особливість. Кожна культура вибудовує свою самобутню систему цінностей, властивістю якої $\epsilon$ трансформація. Ідеологічна і соціальна нестабільність у країні, низький рівень моральних цінностей, невлаштованість підростаючого покоління зумовили наростання в суспільстві соціальної тривожності, невпевненості у майбутньому, агресивності й жорстокості. Такі реалії життя ускладнили процес виховання дітей та молоді, створили передумови для кризи духовно-ціннісних орієнтацій суспільства. Для вирішення перелічених (i не лише) проблем суспільству 
ISSN 2077-1827. Гуманізація навчально-виховного процесу. 2020, №. 1 (99)

РОЗДІЛ. ДОШКІЛЬНЕ ВИХОВАННЯ

необхідно створювати умови для гуманізації освітнього процесу та демократизації стосунків між його учасниками, де в центрі уваги - людина як найвища соціальна цінність, якій буде забезпечуватися повне розкриття іiі можливостей і здібностей, а пріоритетом стануть загальнолюдські цінності та гармонічні стосунків 3 навколишнім світом.

У контексті переосмислення цінностей сучасного етапу розвитку України особливо важливою $\epsilon$ проблема визначення змісту та характеру втілення цінностей у навчально-виховному процесі. Освітні установи різного типу та рівня повинні формувати цінності молоді цілеспрямовано. Зазвичай до ціннісних настанов, які закладає система освіти, входять цінності гуманізму, творчості, співпраці і таке інше. Консолідуючими у складі комплексу цінностей стають гуманістичні, що спрямовані на свободу особистості, демократію, співтворчість і творчу взаємодію в суспільстві. Втілення в життя гуманістичних ідей нерозривно пов'язана із розвитком та вихованням толерантної особистості.

Формуванню толерантності сприяють знання, відкритість, спілкування, свобода думки, совісті й переконань. Толерантність не притаманна людині від народження, і може ніколи й не з'явитися, якщо не буде спеціально вихована, сформована. Шлях до толерантності - це емоційна, інтелектуальна праця, оскільки іiі досягнення можливе лише на основі зміни самого себе, власних стереотипів та свідомості. Толерантність як цінність людства пов'язана 3 суттєвими характеристиками людського буття. Вона є запорукою того, що життя людства продовжиться, а цілісність і розвиток особистості - можливі. Толерантність у ціннісному контексті припускає готовність сприйняття інших такими, якими вони є, і взаємодію з ними на основі згоди.

Значна кількість програмних документів (Закон України «Про дошкільну освіту», Закон України «Про охорону дитинства», «Базовий компонент дошкільної освіти в Україні», програма розвитку дітей дошкільного віку «Я у світі» та ін.) проголошують необхідність створення толерантного суспільства і в нашій країні, адже визначають, що забезпечення виживання, розвитку та захисту прав кожної дитини є обов'язком для держави та суспільства. На підставі аналізу різних підходів до толерантності, формулювань значень цього терміну ми дійшли висновку, що у науковій літературі толерантність розглядається переважно як соціальна цінність, норма соціального життя, принцип людських взаємовідносин, поведінки, особистісна якість і окреслена як повага і визнання рівності, відмова від домінування і насильства, визнання багатовимірності і різноманіття людської культури, норм, вірувань і відмова від зведення цього різноманіття до якоїсь однієї точки зору [5].

У науковому доробку низки вчених (Ш. Амонашвілі, А. Асмолов, І. Бех, А. Богуш, О. Коберник, Т. Кравченко, В. Кремень, В. Кузь, В. Маралов, А. Маслоу, Н. Побірченко, О. Пометун, І. Рогальська, В. Сітаров, О. Сухомлинська та ін.) також акцентується на необхідності якомога раніше знайомити дітей з гуманістичними поняттями, моральними уявленнями, навчати доброті, виховувати в них відповідні особистісні властивості. Найбільш сенситивним періодом розвитку в цьому плані $\epsilon$ дошкільний вік. Саме в цей період у дитини відбувається перехід від егоцентризму до центрації як передумови знаходження свого місця в системі можливих точок зору, встановлення між іншими людьми та власним «Я» системи спільних і взаємних стосунків. Необхідність виховання толерантних взаємостосунків, як однієї із якостей гуманних міжособистісних стосунків пов'язана 3 тим, що сьогодні 
ISSN 2077-1827. Гуманізація навчально-виховного процесу. 2020, №. 1 (99)

РОЗДІЛ. ДОШКІЛЬНЕ ВИХОВАННЯ

насамперед актуальні цінності і принципи, необхідні для загального виживання i вільного розвитку кожного члена суспільства, тобто стратегії ненасильства, терпимості до чужої позиції, цінностей, культури, ідеології; необхідності до взаємного порозуміння, пошуку компромісів у вирішенні будь-яких питань.

У загальноприйнятому контексті толерантність - це якість особистості, яка базується на прагненні прийняти і зрозуміти точку зору іншого, ні в якому разі не спростовуючи впевненість у власних позиціях; здібності до розумного компромісу, що переслідує мету культурного 3'ясування розбіжностей [2; 4]. Толерантна особистість продовжує формуватися у школі та вищому навчальному закладі. Всі ці соціальні інститути сприяють формуванню толерантності як внутрішньої згоди суб'єкта із самим собою, як способу існування особистості, який веде до ії самоствердження.

Незважаючи на різні підходи щодо трактування толерантності, науковці одностайні у тому, що найпершим і найважливішим пї інститутом $\epsilon$ сім я. Головний психолого-педагогічний принцип у системі дошкільної освіти пріоритет сімейного виховання. Центральною функцією сім’ї завжди було виховання дітей. Сім'я $є$ першим та найважливішим інститутом формування особистісного фундаменту в період дошкільного дитинства. Сім'я - це спільність людей, які пов'язані подружнім життя, батьківством, родинністю. Вона грунтується на єдиній загальносімейній діяльності, відтворенні населення та наступності сімейних поколінь. Сім'я повинна брати на себе 3 перших днів життя дитини турботу про іiі здоров'я і виховання, допомагаючи їй пізнавати світ, сприяючи виробленню певних уявлень і навичок, здійсненню контактів 3 іншими людьми [1].

Значення сім’ї у формуванні толерантності дитини, становленні ціннісних орієнтацій величезне. У родині, по-перше, об'єднанні люди різного віку, статі, роду занять; по-друге, дорослі члени родини можуть впливати на дитину в різних життєвих ситуаціях. Звичайно, лише структура сім'ї, кількісний склад не визначають іï виховних впливів, оскільки провідним чинником тут $є$ якісні характеристики - гармонійність взаємин між членами родини, позитивний психологічний клімат, пріоритет духовних цінностей, високий рівень культури.

Від народження у своєму характері, поведінці кожен індивід має добрі і погані спадкові риси: альтруїзм та егоїзм, милосердя і жорстокість, схильність до агресії, насильства чи здатність прощати, створювати дружню атмосферу. Жодну із цих спадкових рис неможливо викорінити. Але кожну можна, більшою чи меншою мірою, розвинути, сформувати чи, навпаки, призупинити іiі подальший розвиток. Для цього родина має будувати свої відносини за допомогою педагогіки толерантності, головним завданням якої $\epsilon$ розвиток здатності до терпіння, витримки, самоконтролю та вміння вирішувати проблемні ситуації без агресії [3]. Педагогіка толерантності передбачає вирішення мирним шляхом суперечностей та конфліктів в освіті, створення соціально-педагогічних умов толерантної взаємодії, культури спілкування, оскільки толерантність $є$ гарантією суспільної стабільності.

Виховання толерантності дошкільників у родині передбачає формування особистості дошкільника, здатної до безкорисної турботи та чуйності, доброзичливих емоційних проявів та емпатії, рівноправного та поступливого ставлення до оточуючих, позитивного прийняття себе та стриманого відстоювання своїх позицій, які виявляються в спілкуванні, вчинках та спільній діяльності. 
ISSN 2077-1827. Гуманізація навчально-виховного процесу. 2020, №. 1 (99)

РОЗДІЛ. ДОШКІЛЬНЕ ВИХОВАННЯ

Висновки 3 даного дослідження і перспективи подалыших розвідок у даному напрямку. Втілення в життя гуманістичних ідей нерозривно пов'язане iз розвитком та вихованням толерантної особистості, яке потрібно починати вже 3 наймолодшого покоління. Виховання толерантності в дошкільників - це, 3 педагогічної точки зору, цілеспрямоване створення соціально-педагогічних умов толерантної взаємодії, культури спілкування. Виховання толерантності майбутніх громадян, які в недалекому майбутньому будуть творити долю не лише нашої держави, але й усієї планети, є гарантією суспільної стабільності, важливою запорукою благополучного майбутнього всього людства.

Формування толерантності у дітей дошкільного віку засобами родинного виховання потребує подальшого вивчення. Виникає необхідність визначення та грунтовного вивчення шляхів, методів та прийомів для розвитку толерантності у молодшого покоління, які передбачали б органічну взаємодію сімейного виховання та педагогічного впливу в закладі дошкільної освіти.

\section{СПИСОК ВИКОРИСТАНОЇ ЛІТЕРАТУРИ}

1. Бєлєнька Г. В. Здоров'я дитини від родини. Як виховати в сім’ї здорову дитину від народження до повноліття. К. : 2006. 157 с

2. Гром С. Сімейне виховання та його вплив на морально-особистісне зростання дошкільників Молодь і ринок. 2012. № 2. С. 160-166.

3. Коток М. Чинники формування особистісної ідентичності старших дошкільників. Вісник Київського національного лінгвістичного університету. Серія Педагогіка та Психологія. 2018. № 28. С. 182-188.

4. Ляпунова В.А. Психолого-педагогічні умови формування толерантності у дітей старшого дошкільного віку Педагогіка та психологія. 2016. Вип. 52. C. 60-69.

5. Ладивір С. Секрети батьківської педагогіки. Дошкільне виховання. 2008. №6. С. 3-6.

Стаття надійшла до редакції 19.12.2019.

\section{КРИВОШЕЯ Неля}

канд. пед. наук, доцент кафедры дошкольного образования, ДВНЗ «Донбасский государственный педагогический университет»

пер. Учительский, 1, г. Славянск, Донецкая область, Украина

E-mail: krivosheyanb@gmail.com

\section{ФОРМИРОВАНИЕ ТОЛЕРАНТНОСТИ} СРЕДСТВАМИ СЕМЕЙНОГО ВОСПИТАНИЯ

Резюме. В статье раскрыта актуальность проблемы формирования толерантности детей дошкольного возраста средствами семейного воспитания. Замечено, что готовность восприятия других такими, какие они есть, и взаимодействовать с ними на основе согласия является залогом возрождения и обогащения высших нравственных идеалов и жизненных приоритетов человека. Автором рассмотрена сущность понятия «толерантность», проанализирована роль гуманистических ценностей общества как определяющих принципов формирования толерантности. Охарактеризована роль семьи и взаимоотношений в семье, обусловливающих формирование толерантности дошкольников. Освещено понятие семейной педагогики толерантности, главной задачей которой определено развитие способности к терпению, выдержки, самоконтроля и умения решать проблемные ситуации без агрессии. Представлены основные 
ISSN 2077-1827. Гуманізація навчально-виховного процесу. 2020, №. 1 (99)

РОЗДІЛ. ДОШКІЛЬНЕ ВИХОВАННЯ

цели воспитания толерантности дошкольников в семье, которое заключается в формировании личности ребенка, способной к бескорыстной заботе и чуткости, доброжелательным эмоциональным проявлениям и эмпатии, равноправному и покладистому отношению к окружающим, положительному принятию себя и сдержанному отстаиванию своих позиций, которые проявляются в общении, поступках и совместной деятельности.

Дальнейшие перспективы исследования автор определяет в изучении путей, методов и приемов органического взаимодействия семейного воспитания и педагогического воздействия в заведении дошкольного образования для развития толерантности дошкольников.

Ключевые слова: дошкольный возраст, ценности, толерантность, формирование личности, семейное воспитание.

\section{KRIVOSHEYA Nelia}

Candidate of Pedagogical Sciences, Associate Professor, Associate Professor of the Department of Preschool Education, SHEI "Donbas State Pedagogical University"

1 Uchytelskyi pr., Sloviansk, Donetsk region, Ukraine

Email: krivosheyanb@gmail.com

\section{DEVELOPING OF A PRESCHOOLER'S TOLERANCE BY MEANS OF FAMILY EDUCATION}

Summary. The article looks into the relevance of the issue of forming preschool children's tolerance by means of family education. The essence of the concept of "tolerance" is defined, the role of humanistic values of society is analysed. The role of the family and relationships in the family is underlined. The concept of family pedagogy of tolerance, whose main task is to develop the capacity for patience, endurance, self-control and the ability to solve problematic situations without aggression, is covered. education.

Keywords: preschool age, values, tolerance, personality formation, family

Abstract. Introduction. One of the main tasks of the modern stage of the education is the development of a child's universal values, among which progressive thinkers have always singled out human rights, freedom, respect for human dignity, caring for people, compassion, and accepting another person, that in the scientific works is defined by the term "tolerance". The article reveals the relevance of the issue of developing tolerance of preschool children by means of family education.

Analysis of publications. Various aspects of tolerance developing are explored in modern pedagogical science: general issues of pedagogy of tolerance, ethnic tolerance, and technological issues of forming tolerance (M. Rozhkov, A. Syrotenko, O. Dokukina, Z. Malkova, T. Bilous, O. Kashchenko, I. Skovorodkina, etc.).

Purpose. The article aims at analysis of the role of family education in developing tolerant behavior of preschool children in the context of modern approaches to personality formation.

Results. It is noted that the willingness to accept others as they are and to interact with them on the basis of consent is a guarantee of the revival and enrichment of the highest moral ideals and vital priorities of man. The author considers the essence of the concept "tolerance", analyzes the role of humanistic values of society as defining principles of the tolerance developing. The role of the family and relationships in the family, which determine the formation of preschool children's tolerance, is characterized. The concept of family pedagogy of tolerance, whose main task is to develop the capacity for patience, endurance, self-control and the ability to 
ISSN 2077-1827. Гуманізація навчально-виховного процесу. 2020, №. 1 (99)

РОЗДІЛ. ДОШКІЛЬНЕ ВИХОВАННЯ

solve problematic situations without aggression, is covered. The main purpose of fostering the preschoolers' tolerance in the family is presented, which consists of the formation of a child's personality, capable of unselfish care and sensitivity, kind emotions and empathy, equal and gentle attitude towards others, positive acceptance and self-esteem, actions and joint activities.

Conclusion. Further perspectives of the study the author defines in the study of ways, methods and techniques of organic interaction of family education and pedagogical influence in the institution of preschool education for the development of preschoolers' tolerance.

\section{REFERENCES}

1. Bielienka, H. V. Bohinych, O. Ya., Mashovets, M. A. (2006). Child's health from the family. How to raise a healthy child in the family from birth to adulthood. Kyiv. [in Ukrainian].

2. Hrom, S. (2012). Family education and its impact on the moral and personal growth of preschoolers. Youth and the market, 2. 160-166. [in Ukrainian].

3. Kotok, M. (2018). Factors of developing personal identity of senior preschoolers. Bulletin of the Kiev National Linguistic University. Series Pedagogy and Psychology, № 28, 182-188. [in Ukrainian].

4. Liapunova, V. A. (2016). Psychological and pedagogical conditions of forming tolerance in children of older preschool age. Pedagogy and psychology, 52, 6069. [in Ukrainian].

5. Ladyvir, S. (2008). Secrets of parental pedagogy. Preschool education, 6, 3-6. [in Ukrainian].

(англійською переклала О. Ішутіна - канд. пед. наук, доцент, доцент кафедри теорії і практики початкової освіти, ДВНЗ «Донбаський державний педагогічний університет»)

\section{УДК 373.2.015.31:7}

\section{ОДЕРІЙ Людмила}

канд. пед. наук, доцент, доцент кафедри дошкільної освіти та соціальної роботи, ДВНЗ «Донбаський державний педагогічний університет»

пров. Учительський 1, м.Слов'янськ, Донецька область, Україна

E-mail: yevhen.rozdymakha@gmail.com

\section{РОЗДИМАХА Анатолій}

канд. пед. наук, доцент, доцент кафедри музики і хореографії, ДВНЗ «Донбаський державний педагогічний університет» вул. Університетська 12, м.Слов'янськ, Донецька область, Україна

E-mail:yevhen.rozdymakha@gmail.com

РОЗВИТОК ХУДОЖНЬОЇ ТВОРЧОСТІ ДІТЕЙ ЗАСОБАМИ НАВЧАННЯ ЕЛЕМЕНТАМ ДИЗАЙНУ У КОНТЕКСТІ ПСИХОЛОГОПЕДАГОГІЧНОГО СУПРОВОДУ ДИТИНСТВА

Анотація. У даній статті розглядається одна з актуальних проблем психологопедагогічного супроводу дитинства - прилучення дітей до мистецтва (с) Одерій Л., Роздимаха А., 2020 